\title{
METABOLISM OF SORBITOL AND FRUCTOSE BY RAM SPERMATOZOA
}

\author{
T. O'SHEA AND R. G. WALES \\ Department of Veterinary Physiology, University of Sydney, \\ Sydney, N.S.W., Australia
}

(Received 9th March 1965)

\begin{abstract}
Summary. The metabolism of sorbitol and fructose by ram spermatozoa has been examined under both aerobic and anaerobic conditions. Isotopically labelled substrates were used to measure substrate oxidation under aerobic conditions or substrate dismutation under anaerobic conditions.

In combination, fructose was used preferentially and, when little or no sorbitol was present at the beginning of incubation, some of the fructose disappearing accumulated as the polyol. The remaining fructose utilized, but not oxidized or dismutated, was quantitatively converted to lactate. When sorbitol was the only substrate in the diluent, it was not utilized under anaerobic conditions and a large part of the sorbitol utilized under aerobic conditions was oxidized. Under the latter conditions, the rate of utilization of the polyol was related to its concentration. It appears that this substrate is made available to the cell by passive diffusion and that this process plays a part in limiting the availability of sorbitol to the cell.

The addition of $10^{-4} \mathrm{M} 2: 4$ dinitrophenol increased oxygen uptake and substrate oxidation when fructose was present in the diluent. With sorbitol as substrate, dinitrophenol decreased substrate oxidation. Under anaerobic conditions, dinitrophenol decreased both sorbitol accumulation from fructose and dismutation of fructose. It is suggested that the dismutation reaction may be linked with the reduction of fructose to sorbitol to balance NAD : NADH ratios.
\end{abstract}

\section{INTRODUCTION}

Sorbitol is present in seminal plasma (King \& Mann, 1959) and is metabolized by ram and bull spermatozoa under aerobic conditions (Mann \& White, 1956, 1957; White, 1957). A nicotinamide adenine dinucleotide (NAD) dependent sorbitol dehydrogenase, first isolated from rat liver by Blakley (1951), is present in ram seminal vesicles (Hers, 1956) and spermatozoa (King \& Mann, $1958,1959)$. Due to the presence of this enzyme, it is probable that the levels of fructose and sorbitol in fresh ram semen are interrelated. However, no full study has been made of their relationship during incubation. In the present paper the relative utilization of fructose and sorbitol by washed and unwashed 
spermatozoa, incubated in the presence of various levels of these substrates, has been examined under both aerobic and anaerobic conditions.

\section{Semen and diluents}

\section{MATERIALS AND METHODS}

Ram semen was collected by electrical stimulation with the bi-polar rectal electrode (Blackshaw, 1954) and only apparently normal ejaculates with good initial motility were used.

The basic diluent consisted of 20 mm-mono- and di-sodium phosphate

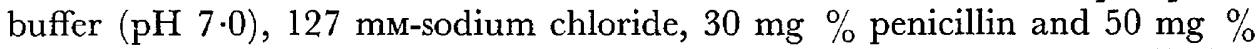
streptomycin. Washed spermatozoal suspensions were obtained by diluting the semen with ten volumes of basic diluent and centrifuging at $400 \mathrm{~g}$ for $7 \mathrm{~min}$. The supernatant was replaced with an equal volume of diluent and the spermatozoa were dispersed and recentrifuged. After removing the second supernatant, the spermatozoa were diluted to the required volume.

For the incubations, fructose and sorbitol, either alone or together, were added to the diluents. Isotonicity was maintained by decreasing the sodium chloride content to compensate for the added substrate. In some experiments $3 \mathrm{~g} \%$ casein was also added to the incubation diluents.

The labelled fructose and sorbitol $\left(\mathrm{D}-\mathrm{U}-{ }^{14} \mathrm{C}\right.$ fructose and $\mathrm{U}-{ }^{14} \mathrm{C}$ sorbitol from the Radiochemical Centre, Amersham, England) used in the experiments were added directly to the incubation flasks as carrier-free isotope in $0.1 \mathrm{ml}$ of isotonic saline. In this way the specific activity of the incubation mixture could be altered from one experiment to another to ensure adequate counts in the trapped carbon dioxide under varying conditions. Where both fructose and sorbitol were present in the same diluent, duplicate Warburg flasks were incubated; one containing labelled fructose and the other labelled sorbitol. By radioactive assay of the trapped carbon dioxide in each flask it was possible to measure the contribution of each substrate to total oxidation.

\section{Incubation of spermatozoa}

All experiments were carried out in a Warburg bath at $37^{\circ} \mathrm{C}$ with a shaking rate of $120 / \mathrm{min}$. In the preliminary experiments (Tables 1 to 3 ) $1 \mathrm{ml}$ of semen suspension containing 1.5 to $3 \times 10^{8}$ spermatozoa was incubated in Warburg flasks of $5 \mathrm{ml}$ volume and potassium hydroxide $(20 \% \mathrm{w} / \mathrm{v})$ was used to trap the evolved $\mathrm{CO}_{2}$.

In the later experiments (Tables 4 to 9) $15 \mathrm{ml}$ double side-arm flasks containing $3 \mathrm{ml}$ of spermatozoal suspension were used. For all anaerobic experiments, the flasks were flushed with nitrogen for 10 min before incubation. Commercial dry nitrogen was successively passed through pyrogallol, concentrated sulphuric acid and silica gel before entering the flasks. In order to ensure complete anaerobiosis in some experiments, a small piece of yellow phosphorus was added to one side-arm immediately prior to gassing. Where aerobic and anaerobic incubations were compared, the suspensions were flushed with air and nitrogen respectively in order to keep a strict comparison of conditions. 
In the anaerobic experiments where only ${ }^{14} \mathrm{CO}_{2}$ produced during the actual incubation was of interest, the spermatozoa were kept separate from the ${ }^{14} \mathrm{C}$ labelled substrate during gassing. In one experiment (Table 6) this was attained by adding the washed spermatozoal suspension to the incubation diluent in the main compartment of the flask and, after gassing, adding the carrier-free isotope from the side-arm. Duplicate flasks for each treatment were gassed and one used to determine the initial specific activities of metabolites. In other experiments (Tables 5, 7, 8 and 9) the washed spermatozoal suspension was placed in the side-arm and the incubation diluent + isotope in the main compartment during the gassing. Metabolism of substrates was initiated by mixing after the system was sealed. After incubation, metabolism was terminated by adding $0 \cdot 1 \mathrm{ml}$ of $6 \mathrm{~N}-\mathrm{H}_{2} \mathrm{SO}_{4}$ to the spermatozoal suspension from one side-arm.

\section{Analytical methods}

At the completion of incubation, protein-free extracts were obtained by precipitation with equal volumes of $5 \% \mathrm{w} / \mathrm{v} \mathrm{ZnSO}_{4} .7 \mathrm{H}_{2} \mathrm{O}$ and $0.3 \mathrm{~N}-\mathrm{Ba}(\mathrm{OH})_{2}$. Where acid had been added the flask contents were neutralized before precipitation. Where necessary, protein-free extracts of semen suspensions, prior to the incubation, were also made. Lactate was determined by the enzymic method described by Barker \& Britton (1957) and fructose by the method of Mann (1948) as modified by White (1959). Sorbitol was measured by the enzymic procedure outlined below. In samples containing $2: 4$ dinitrophenol the assay of both lactate and sorbitol was corrected for absorption by dinitrophenol at $366 \mathrm{~m} \mu$. Preliminary tests had shown that under the conditions of assay, $10^{-4} \mathrm{M}$-dinitrophenol did not affect the determinations.

Substrate oxidation was calculated from the assay of radioactivity of the trapped carbon dioxide and the specific activity of the substrates at the beginning of incubation. In the experiments using washed spermatozoa, fructose and lactate could not be detected after washing and the oxygen uptake not attributable to oxidation of added substrate presumably came from the oxidation of endogenous reserves and has been referred to as endogenous oxygen uptake.

In experiments conducted under strictly anaerobic conditions, Terner (1959) has shown that $\mathrm{CO}_{2}$ can arise from the dismutation reaction

$$
2 \mathrm{CH}_{3} \mathrm{CO} . \mathrm{COOH}+\mathrm{CoASH} \rightarrow \mathrm{CH}_{3} \mathrm{CH}(\mathrm{OH}) \mathrm{COOH}+\mathrm{CH}_{3} \mathrm{COSCoA}+\mathrm{CO}_{2}
$$

Rothschild (1964) has postulated a second anaerobic reaction leading to the formation of $\mathrm{CO}_{2}$ :

$$
3 \mathrm{C}_{6} \mathrm{H}_{12} \mathrm{O}_{6}+2 \mathrm{H}_{2} \mathrm{O} \rightarrow 2 \mathrm{CH}_{3} \mathrm{COOH}+4 \mathrm{CH}_{2}(\mathrm{OH}) \mathrm{CH}(\mathrm{OH}) \mathrm{CH}_{2}(\mathrm{OH})+2 \mathrm{CO}_{2}
$$

However, for the purposes of this paper, the ${ }^{14} \mathrm{CO}_{2}$ produced under anaerobic conditions has been assumed to arise from the dismutation reaction and has been calculated in terms of $\mu$ moles of substrate dismutated $/ 10^{8}$ cells over the experimental period.

For each experiment, spermatozoal counts were made either by optical density measurements at $625 \mathrm{~m} \mu$ or by direct counts in a haemocytometer. All results are expressed as $\mu$ moles $/ 10^{8}$ spermatozoa over the experimental 
period. The term lactate accumulation refers to the difference between final and initial lactate levels and thus total lactate formed during the incubation equals lactate accumulated plus lactate oxidized.

\section{Estimation of sorbitol}

Preparation of sorbitol dehydrogenase. The enzyme was obtained from rat livers by a method based on a preparation described by Blakley (1951). All steps were carried out at 0 to $3^{\circ} \mathrm{C}$ and centrifugations were for $15 \mathrm{~min}$ at $4000 \mathrm{~g}$. Rat livers were homogenized $1 \mathrm{~min}$ in $0.01 \mathrm{M}$-phosphate buffer ( $\mathrm{pH} \mathrm{7.8)}$. After centrifugation, iso-electric precipitation (at $\mathrm{pH} 4.0$ ) and recentrifugation, the supernatant was extracted with chloroform-ethanol at room temperature and the aqueous phase dialysed against distilled water for $48 \mathrm{hr}$. The enzyme was precipitated with ammonium sulphate (Blakley, 1951) and extensively dialysed against $0.002 \mathrm{M}$-phosphate buffer ( $\mathrm{pH} \mathrm{7.8)}$. After checking for the level of activity against sorbitol and for lack of activity against lactate, the preparations were stored at $-40^{\circ} \mathrm{C}$ until required.

Assay of sorbitol. The assay was based on the properties of the enzyme as described by Blakley (1951) and King \& Mann (1959). As noted by Wolfson \& Williams-Ashman (1958), reduction of NAD in the reaction was depressed by the presence of fructose. This was especially important where the fructose to sorbitol ratio was large. Thus, when the fructose to sorbitol ratio was $1: 1$, only a $10 \%$ depression in the reduction of NAD occurred. When this ratio increased to $5: 1$, there was a $50 \%$ depression. However, a straight line relationship was always maintained between sorbitol concentration and optical density and, to compensate for the depression, fructose was added to the sorbitol standards and reagent blanks at the level found in the experimental samples.

For the assay, the volume of enzyme preparation varied with batches but was kept at twice the minimum amount required. The method used was as follows:

To the deproteinized sample were added (a) phosphate buffer ( $\mathrm{pH} 7 \cdot 8$ to final concentration of $0.08 \mathrm{M}$ ), (b) the enzyme aliquot and (c) $4 \mathrm{mg}$ NAD in a final volume of $2.5 \mathrm{ml}$. After incubation at $37^{\circ} \mathrm{G}$ for $30 \mathrm{~min}$, the reaction was stopped by cooling to $25^{\circ} \mathrm{C}$ and, where opacity had developed during the reaction, the samples were centrifuged at $5^{\circ} \mathrm{C}$. Optical densities were measured at 366 or $340 \mathrm{~m} \mu$ against a reagent blank and quantitative values were obtained by comparison with optical densities of sorbitol standards.

\section{Assay of radioactivity}

In the preliminary experiments, the radioactivity of the trapped carbon dioxide was measured by liquid scintillation spectrometry (Buhler, 1962). However, this method is not specific for trapped ${ }^{14} \mathrm{CO}_{2}$ and the occasional contamination of the centre well with isotopic substrate during the experiment caused a spurious elevation of counts. In these cases, recovery of the isotope from the scintillation mixture, precipitation as $\mathrm{Ba}^{14} \mathrm{CO}_{3}$ and counting of the precipitate by the method of Annison \& White (1961) reduced the counts to those that would have been expected from the oxygen data. In the 
later experiments the assay of ${ }^{14} \mathrm{CO}_{2}$ was carried out by precipitation as $\mathrm{Ba}^{14} \mathrm{CO}_{3}$, counting with an end window Geiger-Mülier tube and correcting for self-absorption by the method of Hendler (1959).

\section{Statistical analysis}

All experiments were of factorial design and the significance of the results has been assessed by the analysis of variance or by the paired $t$-test where only two means were involved. In the experiments where duplicate samples were tested, the variance between duplicates was used as error except in those cases where the higher order interaction variance was significantly greater than the variance between duplicates. In the smaller experiments, pooled ejaculate interactions were used as error. In the Tables the analyses are presented in summary form giving only degrees of freedom (d.f.) and variance ratios for each source of variation. The error variance is given in italics at the base of the variance ratio column and asterisks are used to denote significant differences.

\section{RESULTS}

In the first experiment, the effect of low levels of sorbitol and a constant initial level of fructose on the metabolism of washed ram spermatozoa was studied. Sorbitol to fructose ratios of $1: 60$ and $1: 3$ were used to cover the range expected in ram semen (see King \& Mann, 1959). To guard against the possibility of low fructose concentration towards the end of the experiments affecting the relative utilization of substrates, the incubations were terminated when approximately $50 \%$ of added fructose was utilized. As this could be roughly estimated from the oxygen utilization data, the incubations were discontinued after a predetermined total oxygen uptake. Results for four ejaculates with the summary of the analyses of variance are given in Table 1 . Fructose was used preferentially and the presence of low levels of sorbitol had no effect on the oxidation of fructose or on endogenous respiration. When no sorbitol was present at the beginning of incubation, approximately $20 \%$ of the fructose disappearing was converted to sorbitol. This accumulation of sorbitol was depressed even when small amounts of this substrate were present and when the fructose to sorbitol ratio equalled $3: 1$, there was quantitative conversion of fructose to lactate and no accumulation of sorbitol.

In the next experiment (Table 2) the effect of high sorbitol to fructose ratios on the metabolism of washed ram spermatozoa was investigated. As in the first experiment, sorbitol accumulated when only fructose was present at the commencement of incubation. The addition of an excess of sorbitol resulted in a small net disappearance of this substrate during the incubation and a decrease in the utilization of fructose. Even when sorbitol levels were high, approximately $80 \%$ of the oxygen uptake was due to the oxidation of fructose.

To examine if there was any effect of the duration of incubation on the relative utilization of fructose and sorbitol, flasks containing $6 \mu$ mole of fructose and varying amounts of sorbitol were incubated for $1 \frac{1}{2}$ or $3 \mathrm{hr}$. So that the substrate concentration in all flasks at the end of the experiments would be 
TABLE 1

METABOLISM OF WASHED RAM SPERMATOZOA IN THE PRESENCE OF A CONSTANT LEVEL OF FRUCTOSE AND VARYING LEVELS OF SORBITOL

\begin{tabular}{|c|c|c|c|c|c|c|c|c|}
\hline $\begin{array}{c}\text { Fructose } \\
\text { conc. } \\
\text { (umolel } \\
\text { flask) }\end{array}$ & $\begin{array}{c}\text { Sorbitol } \\
\text { conc. } \\
\text { ( } \begin{array}{c}\text { molel } \\
\text { flask) }\end{array}\end{array}$ & $\begin{array}{c}\text { Total } \\
\mathrm{O}_{2} \\
\text { uptake }\end{array}$ & $\begin{array}{l}\text { Fructose } \\
\text { oxidized }\end{array}$ & $\begin{array}{l}\text { Sorbitol } \\
\text { oxidized }\end{array}$ & $\begin{array}{l}\text { Endogen- } \\
\text { ous } \mathrm{O}_{2} \\
\text { uptake }\end{array}$ & $\begin{array}{c}\text { Fructose } \\
\text { utilized }\end{array}$ & $\begin{array}{c}\text { Sorbitol } \\
\text { accumu- } \\
\text { lated }\end{array}$ & $\begin{array}{c}\text { Lactate } \\
\text { accumu- } \\
\text { lated }\end{array}$ \\
\hline 6 & 0 & 1.73 & 0.235 & 0.0000 & 0.32 & 1.65 & 0.38 & 1.87 \\
\hline 6 & 0.1 & 1.75 & 0.243 & 0.0006 & 0.29 & 1.64 & 0.28 & $1 \cdot 80$ \\
\hline 6 & $2 \cdot 0$ & 1.88 & 0.243 & 0.0111 & $0 \cdot 35$ & $1 \cdot 59$ & -0.01 & $2 \cdot 00$ \\
\hline
\end{tabular}

Values are expressed as $\mu$ mole $/ 10^{8}$ spermatozoa over the experimental period (2 to $3 \mathrm{hr}$ ) and are the means for four ejaculates.

Summary of the analyses of variance

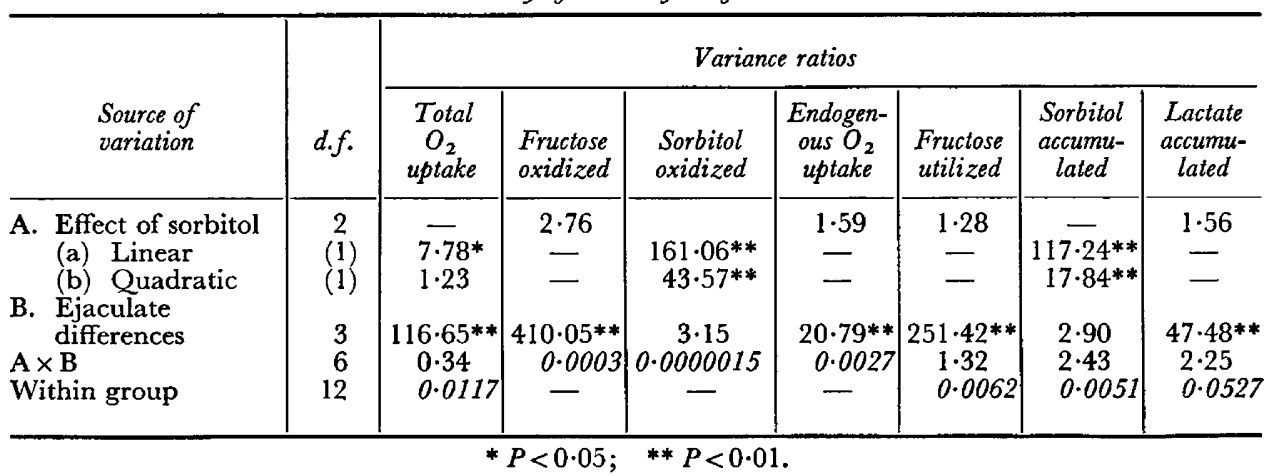

TABLE 2

METABOLISM OF WASHED RAM SPERMATOZOA IN THE PRESENGE OF A CONSTANT LEVEL (6 $\mu$ MOLE/FLASK) OF FRUCTOSE WITH AND WITHOUT THE ADDITION OF A HIGH LEVEL (12 $\mu$ MOLE/FLASK) OF SORBITOL

\begin{tabular}{c|c|c|c|c|c|c|c}
\hline $\begin{array}{c}\text { Sorbitol } \\
\text { conc. } \\
(\mu \mathrm{mole} / \text { flask) }\end{array}$ & $\begin{array}{c}\text { Total } \\
\mathrm{O}_{2} \\
\text { uptake }\end{array}$ & $\begin{array}{c}\text { Fructose } \\
\text { oxidized }\end{array}$ & $\begin{array}{c}\text { Sorbitol } \\
\text { oxidized }\end{array}$ & $\begin{array}{c}\text { Endogen- } \\
\text { ous } \\
\text { uptake }\end{array}$ & $\begin{array}{c}\text { Fructose } \\
\text { utilized }\end{array}$ & $\begin{array}{c}\text { Sorbitol } \\
\text { accumulated }\end{array}$ & $\begin{array}{c}\text { Lactate } \\
\text { accumulated }\end{array}$ \\
\hline 0 & 1.65 & 0.181 & 0.000 & 0.46 & 1.06 & 0.19 & $1 \cdot 48$ \\
12 & 1.74 & 0.172 & 0.040 & 0.45 & 0.71 & -0.30 & 1.28 \\
\hline
\end{tabular}

Values are expressed as $\mu$ mole $/ 10^{8}$ spermatozoa over the experimental period ( $1 \frac{1}{2}$ to $3 \mathrm{hr}$ ) and are the same for four ejaculates.

Summary of the analyses of variance

\begin{tabular}{l|c|c|c|c|c}
\hline & & \multicolumn{4}{|c}{ Variance ratios } \\
\cline { 3 - 6 } \multicolumn{1}{c|}{ Source of variation } & d.f. & $\begin{array}{c}\text { Total } O_{2} \\
\text { uptake }\end{array}$ & $\begin{array}{c}\text { Fructose } \\
\text { utilized }\end{array}$ & $\begin{array}{c}\text { Sorbitol } \\
\text { accumulated }\end{array}$ & $\begin{array}{c}\text { Lactate } \\
\text { accumulated }\end{array}$ \\
\hline A. Effect of sorbitol & 1 & $0 \cdot 79$ & $12 \cdot 15^{* *}$ & $83 \cdot 53^{* *}$ & $4 \cdot 79$ \\
B. Ejaculate differences & 3 & $17 \cdot 22 * *$ & $12 \cdot 54^{* *}$ & $2 \cdot 17$ & $20 \cdot 43^{* *}$ \\
A $\times$ B & 3 & $0 \cdot 98$ & $3 \cdot 45$ & $4 \cdot 92^{*}$ & $1 \cdot 36$ \\
Within group (error) & 8 & 0.0356 & $0 \cdot 0412$ & $0 \cdot 0113$ & $0 \cdot 0342$ \\
\hline
\end{tabular}

$* P<0.05 ; \quad * * P<0.01$. 
similar, the concentration of spermatozoa in the flasks incubated for $3 \mathrm{hr}$ $\left(1.2 \times 10^{8}\right.$ cells $\left./ \mathrm{ml}\right)$ was half that in the flasks incubated for $1 \frac{1}{2} \mathrm{hr}$. The results for four replicates and the summary of the analyses of variance are presented in Table 3. During the incubation for $1 \frac{1}{2} \mathrm{hr}$, there was very little utilization or oxidation of sorbitol, even when the sorbitol to fructose ratio was $2: 1$.

TABLE 3

EFFECT OF TIME ON THE METABOLISM OF WASHED RAM SPERMATOZOA IN THE PRESENCE OF FRUCTOSE ( $6 \mu$ MOLE/FLASK) AND SORBITOL

\begin{tabular}{|c|c|c|c|c|c|c|c|c|}
\hline $\begin{array}{c}\text { Time } \\
(h r)\end{array}$ & $\begin{array}{c}\text { Sorbitol } \\
\text { conc. } \\
\text { (umolel } \\
\text { flask) }\end{array}$ & $\begin{array}{c}\text { Total } \\
\mathrm{O}_{2} \\
\text { uptake }\end{array}$ & $\begin{array}{l}\text { Fructose } \\
\text { oxidized }\end{array}$ & $\begin{array}{l}\text { Sorbitol } \\
\text { oxidized }\end{array}$ & $\begin{array}{c}\text { Endogen- } \\
\text { ous } \mathrm{O}_{2} \\
\text { uptake }\end{array}$ & $\begin{array}{l}\text { Fructose } \\
\text { utilized }\end{array}$ & $\begin{array}{c}\text { Sorbitol } \\
\text { accumulated }\end{array}$ & $\begin{array}{c}\text { Lactate } \\
\text { accumulated }\end{array}$ \\
\hline $1 \frac{1}{2}$ & $\begin{array}{r}0 \\
4 \\
12\end{array}$ & $\begin{array}{l}1.55 \\
1.59 \\
1.68\end{array}$ & $\begin{array}{l}0.226 \\
0.203 \\
0.198\end{array}$ & $\begin{array}{l}0.000 \\
0.017 \\
0.028\end{array}$ & $\begin{array}{l}0 \cdot 19 \\
0 \cdot 29 \\
0 \cdot 34\end{array}$ & $\begin{array}{l}1.24 \\
0.89 \\
0.87\end{array}$ & $\begin{array}{r}0.12 \\
0.06 \\
-0.03\end{array}$ & $\begin{array}{l}1.38 \\
1.42 \\
1.43\end{array}$ \\
\hline 3 & $\begin{array}{r}0 \\
4 \\
12\end{array}$ & $\begin{array}{l}2 \cdot 30 \\
2 \cdot 26 \\
2 \cdot 45\end{array}$ & $\begin{array}{l}0.357 \\
0.313 \\
0.276\end{array}$ & $\begin{array}{l}0.000 \\
0.022 \\
0 \cdot 142\end{array}$ & $\begin{array}{r}0 \cdot 16 \\
0 \cdot 24 \\
-0 \cdot 10\end{array}$ & $\begin{array}{l}1.94 \\
1.68 \\
1.29\end{array}$ & $\begin{array}{r}0.24 \\
-0.15 \\
-0.39\end{array}$ & $\begin{array}{l}2 \cdot 48 \\
2 \cdot 38 \\
2 \cdot 23\end{array}$ \\
\hline
\end{tabular}

All values are expressed as $\mu$ mole $/ 10^{8}$ spermatozoa over the experimental period and are the means for four ejaculates.

Summary of the analyses of variance

\begin{tabular}{|c|c|c|c|c|c|c|c|c|}
\hline \multirow[b]{2}{*}{ Source of variation } & \multirow[b]{2}{*}{$d . f}$. & \multicolumn{7}{|c|}{ Variance ratios } \\
\hline & & $\begin{array}{c}\text { Total } \\
\mathrm{O}_{2} \\
\text { uptake }\end{array}$ & $\begin{array}{l}\text { Fructose } \\
\text { oxidized }\end{array}$ & $\begin{array}{c}\text { Sorbitol } \\
\text { oxidized }\end{array}$ & $\begin{array}{c}\text { Endogen- } \\
\text { ous } \mathrm{O}_{2} \\
\text { uptake }\end{array}$ & $\begin{array}{l}\text { Fructose } \\
\text { utilized }\end{array}$ & $\begin{array}{c}\text { Sorbitol } \\
\text { accumu- } \\
\text { lated }\end{array}$ & $\begin{array}{c}\text { Lactate } \\
\text { accumu- } \\
\text { lated }\end{array}$ \\
\hline A. Sorbitol level & 2 & - & - & - & $1 \cdot 17$ & - & _- & 0.34 \\
\hline Linear & (1) & $16 \cdot 80^{* *}$ & $18 \cdot 79 * *$ & $833 \cdot 17 * *$ & - & $34 \cdot 45 * *$ & $21 \cdot 31 * *$ & - \\
\hline Quadratic & (1) & $5 \cdot 11^{*}$ & $0 \cdot 30$ & $97 \cdot 61^{* *}$ & - & 0.46 & 0.14 & 0105 \\
\hline B. Time & 1 & $691 \cdot 96^{* *}$ & $107 \cdot 30^{* *}$ & $292 \cdot 49 * *$ & $4 \cdot 90$ & $81 \cdot 51 * *$ & $4 \cdot 70^{*}$ & $91 \cdot 25$ \\
\hline $\begin{array}{l}\text { C. Ejaculate } \\
\text { differences }\end{array}$ & 3 & $24 \cdot 43^{* *}$ & $6 \cdot 17 *$ & 0.26 & 0.20 & $7 \cdot 49 * *$ & 0.26 & $6 \cdot 69^{* *}$ \\
\hline $\begin{array}{l}\text { Interactions } \\
A \times B\end{array}$ & 2 & 1.16 & & $299.97 * *$ & & & $4.20 *$ & 0.78 \\
\hline $\mathrm{A} \times \mathrm{C}$ & 6 & 1.37 & 0.41 & 0.70 & 0.42 & 1.40 & 1.64 & $\begin{array}{l}0.78 \\
0.77\end{array}$ \\
\hline $\mathrm{B} \times \mathrm{C}$ & 3 & $21 \cdot 86 * *$ & $9 \cdot 69^{*}$ & 0.38 & 1.52 & 1.80 & 1.05 & 1.26 \\
\hline $\mathrm{A} \times \mathrm{B} \times \mathrm{C}$ & 6 & $2 \cdot 18$ & 0.0006 & 0.00003 & 0.0361 & $2 \cdot 44$ & 1.53 & 1.33 \\
\hline Within group & 24 & 0.0093 & - & - & - & 0.0604 & 0.0568 & 0.1204 \\
\hline
\end{tabular}

* $P<0.05 ; \quad * * P<0.01$.

Over the longer incubation, however, both utilization and oxidation of sorbitol were increased considerably at high sorbitol levels. When the concentration of sorbitol was similar to that of fructose, the spermatozoa showed little activity towards sorbitol either during the short or long incubation period.

In all the above experiments, there was usually a small significant increase in total oxygen uptake when sorbitol was included in the incubation medium. To test if this increase was due to variations in total available substrate, the effects of incubating washed ram spermatozoa in the presence of $6 \mu$ mole and $18 \mu$ mole of fructose/flask were investigated. In tests on four ejaculates, there 
was no effect of fructose level on total oxygen uptake, fructose oxidation, endogenous respiration, fructose disappearance or lactate accumulation.

As washed ram spermatozoa were used in all the preceding experiments, a comparison of the metabolism of washed and unwashed spermatozoa was made under both aerobic and anaerobic conditions. Spermatozoa (6 to $8 \times 10^{8}$ cells/flask) were incubated in double side-arm Warburg flasks in the presence of $24 \mu$ mole fructose and $9 \mu$ mole sorbitol/flask and the results together with the summary of the analyses of variance are given in Table 4. Labelled substrates were not included in this experiment and consequently only data for

\section{TABLE 4}

FRUCTOSE UTILIZATION AND SORBITOL AND LACTATE ACCUMULATION OF WASHED AND UNWASHED RAM SPERMATOZOA UNDER AEROBIC AND ANAEROBIC CONDITIONS

\begin{tabular}{c|c|c|c|c|c}
\hline Treatment & Gas phase & $\begin{array}{c}\text { Total } \mathrm{O}_{2} \\
\text { uptake }\end{array}$ & $\begin{array}{c}\text { Fructose } \\
\text { utilized }\end{array}$ & $\begin{array}{c}\text { Sorbitol } \\
\text { accumulated }\end{array}$ & $\begin{array}{c}\text { Lactate } \\
\text { accumulated }\end{array}$ \\
\hline Unwashed & Air & 1.71 & 1.01 & 0.02 & 1.64 \\
& $\mathrm{~N}_{2}$ & - & 2.28 & 0.40 & 3.77 \\
Washed & Air & $1.41 \dagger$ & 1.02 & 0.01 & 1.51 \\
& $\mathrm{~N}_{2}$ & - & 1.79 & 0.43 & 2.75 \\
\hline
\end{tabular}

All results are expressed as $\mu$ mole $/ 10^{8}$ spermatozoa over the experimental period $\left(2 \frac{1}{2} \mathrm{hr}\right)$ and are the means for three ejaculates incubated in the presence of $24 \mu$ moles fructose and $9 \mu$ moles of sorbitol/flask.

Summary of the analyses of variance

\begin{tabular}{|c|c|c|c|c|}
\hline \multirow[b]{2}{*}{ Source of variation } & \multirow[b]{2}{*}{ d.f. } & \multicolumn{3}{|c|}{ Variance ratios } \\
\hline & & $\begin{array}{l}\text { Fructose } \\
\text { utilized }\end{array}$ & $\begin{array}{c}\text { Sorbitol } \\
\text { accumulated }\end{array}$ & $\begin{array}{c}\text { Lactate } \\
\text { accumulated }\end{array}$ \\
\hline $\begin{array}{l}\text { A. Effect of gas phase } \\
\text { B. Effect of washing } \\
\mathbf{A} \times \mathbf{B} \\
\text { Ejaculate differences } \\
\text { Ejaculate interactions } \\
\text { (error) }\end{array}$ & $\begin{array}{l}1 \\
1 \\
1 \\
2 \\
6\end{array}$ & $\begin{array}{l}65 \cdot 26^{* *} \\
3 \cdot 52 \\
4 \cdot 04 \\
1.50 \\
0.0474\end{array}$ & $\begin{array}{l}22.37 * * \\
0.02 \\
0.06 \\
0.52 \\
0.0219\end{array}$ & $\begin{array}{c}346 \cdot 70^{* *} \\
40 \cdot 76^{* *} \\
24 \cdot 22 * * \\
3 \cdot 69 \\
0 \cdot 0245\end{array}$ \\
\hline
\end{tabular}

$\dagger$ Significant decrease in $\mathrm{O}_{2}$ uptake, $P<0.01$.

total oxygen consumption are presented. There was little difference between the metabolism of washed and unwashed spermatozoa under aerobic conditions. Approximately 75 to $80 \%$ of the utilized fructose appeared as lactate while only 1 to $2 \%$ accumulated as sorbitol. Oxygen uptake of the washed suspension could account for the remaining $20 \%$ of the fructose utilized in these samples. In the unwashed suspensions where other substrates may also be present, oxygen uptake was greater than that required to oxidize the fructose not accumulating as lactate. Under anaerobic conditions, fructose utilization and lactate accumulation were slightly depressed by washing. In both cases, however, approximately $80 \%$ of utilized fructose accumulated as lactate and the remaining $20 \%$ as sorbitol. 
A comparison of the metabolism of washed ram spermatozoa ( 2 to $5 \times 10^{8}$ cells/flask) with fructose or sorbitol as sole substrate ( $30 \mu \mathrm{mole} /$ flask) is given in Table 5. Incubations were carried out either under aerobic conditions or after complete exclusion of oxygen. The results for three ejaculates are presented in Table 5. Total oxygen uptake was greater in the presence of sorbitol even though the oxidation of this substrate was not significantly different from that of fructose. When sorbitol was the sole substrate, the small percentage utilized

TABle 5

METABOLISM OF WASHED RAM SPERMATOZOA IN THE PRESENCE OF FRUCTOSE OR SORBITOL

\begin{tabular}{|c|c|c|c|c|c|c|c|c|}
\hline $\begin{array}{c}\text { Gas } \\
\text { phase }\end{array}$ & $\begin{array}{l}\text { Substrate } \\
\text { added }\end{array}$ & $\begin{array}{c}\text { Total } \\
\mathrm{O}_{2} \\
\text { uptake }\end{array}$ & $\begin{array}{l}\text { Substrate } \\
\text { oxidized }\end{array}$ & $\begin{array}{c}\text { Endogen- } \\
\text { ous } \mathrm{O}_{2} \\
\text { uptake }\end{array}$ & $\begin{array}{l}\text { Fructose } \\
\text { utilized }\end{array}$ & $\begin{array}{c}\text { Lactate } \\
\text { accumu- } \\
\text { lated }\end{array}$ & $\begin{array}{c}\text { Sorbitol } \\
\text { accumu- } \\
\text { lated }\end{array}$ & $\begin{array}{c}\text { Substrate } \\
\text { dis- } \\
\text { mutated }\end{array}$ \\
\hline Air & $\begin{array}{l}\text { Fructose } \\
\text { Sorbitol }\end{array}$ & $\begin{array}{l}2 \cdot 33 \\
2 \cdot 41^{*}\end{array}$ & $\begin{array}{l}0.268 \\
0.204\end{array}$ & $\begin{array}{l}0.73 \\
1.08\end{array}$ & $1 \cdot 61$ & $\frac{2 \cdot 36}{-}$ & $\frac{0 \cdot 27}{-}$ & - \\
\hline Nitrogen & $\begin{array}{l}\text { Fructose } \\
\text { Sorbitol }\end{array}$ & - & - & - & $\frac{2 \cdot 65^{*}}{-}$ & $\frac{4 \cdot 39 *}{-}$ & $\frac{0.46^{*}}{-}$ & $\begin{array}{l}0.30 \\
0.03^{*}\end{array}$ \\
\hline
\end{tabular}

Values are expressed as $\mu$ moles $/ 10^{8}$ spermatozoa over the experimental period ( $3 \mathrm{hr}$ ) and are the means for three ejaculates.

* Significant difference between means, $P<0.05$.

TABLE 6

EFFECT OF DINITROPHENOL $\left(10^{-4} \mathrm{M}\right)$ ON THE ANAEROBIC METABOLISM OF WASHED RAM SPERMATOZOA

\begin{tabular}{c|c|c|c|c}
\hline Treatment & $\begin{array}{c}\text { Fructose } \\
\text { utilized }\end{array}$ & $\begin{array}{c}\text { Sorbitol } \\
\text { accumulated }\end{array}$ & $\begin{array}{c}\text { Lactate } \\
\text { accumulated }\end{array}$ & $\begin{array}{c}\text { Fructose } \\
\text { dismutated }\end{array}$ \\
\hline - Dinitrophenol & 1.43 & 0.09 & 1.51 & 0.066 \\
+ Dinitrophenol & 1.03 & 0.08 & 1.47 & $0.008^{*}$ \\
\hline
\end{tabular}

Values are expressed as $\mu$ mole $/ 10^{8}$ cells over the experimental period $(3 \mathrm{hr}$ ) and are the means for three ejaculates incubated in the presence of $20 \mu$ mole fructose and $10 \mu$ mole sorbitol per flask.

* Significant effect of dinitrophenol, $P<0.05$.

could not be measured accurately. Under anaerobic conditions, fructose utilization was increased; there was an increase in the formation of sorbitol from fructose and at the same time, an appreciable dismutation of fructose.

In further studies the effect of $10^{-4} \mathrm{M} 2: 4$ dinitrophenol on the anaerobic metabolism of washed ram spermatozoa was examined. Three ejaculates of washed spermatozoa ( 6 to $9 \times 10^{8}$ cells/flask) were incubated in the presence of $20 \mu \mathrm{mole}$ of fructose and $10 \mu \mathrm{mole}$ of sorbitol/flask and the results are summarized in Table 6 . There was a significant decrease in fructose utilized and in fructose dismutated in the presence of dinitrophenol.

In the next experiment (Table 7) the effect of dinitrophenol $\left(10^{-4} \mathrm{M}\right)$ on the metabolism of washed ram spermatozoa (2 to $3 \times 10^{8}$ cells/flask) was compared under aerobic and strictly anaerobic conditions in the presence of 
$25 \mu$ mole of fructose and $10 \mu$ mole of sorbitol/flask. Oxygen uptake and fructose oxidation were doubled by the addition of dinitrophenol and at the same time aerobic fructolysis was increased $50 \%$ with a corresponding increase in lactate accumulation. Under anaerobic conditions, however, fructose utilization was slightly depressed by dinitrophenol. At the same time, there was a decrease in the amount of fructose dismutated and agreement in carbon balance was good.

TABLE 7

EFFECT OF $2: 4$ DINITROPHENOL $\left(10^{-4} \mathrm{M}\right)$ ON THE METABOLISM OF WASHED RAM SPERMATOZOA UNDER AEROBIC AND ANAEROBIC CONDITIONS

\begin{tabular}{|c|c|c|c|c|c|c|c|}
\hline $\begin{array}{c}\text { Gas } \\
\text { phase }\end{array}$ & Treatment & $\begin{array}{c}\text { Total } \mathrm{O}_{2} \\
\text { uptake }\end{array}$ & $\begin{array}{l}\text { Fructose } \\
\text { oxidized }\end{array}$ & $\begin{array}{l}\text { Fructose } \\
\text { utilized }\end{array}$ & $\begin{array}{c}\text { Lactate } \\
\text { accumulated }\end{array}$ & $\begin{array}{c}\text { Sorbitol } \\
\text { accumulated }\end{array}$ & $\begin{array}{c}\text { Fructose } \\
\text { dismutated }\end{array}$ \\
\hline Air & $\begin{array}{l}-\mathrm{DNP} \\
+\mathrm{DNP}\end{array}$ & $\begin{array}{l}1 \cdot 91 \\
4 \cdot 54 \dagger\end{array}$ & $\begin{array}{l}0.254 \\
0.588 \dagger\end{array}$ & $\begin{array}{l}1 \cdot 10 \\
1 \cdot 70\end{array}$ & $\begin{array}{l}1 \cdot 97 \\
2 \cdot 29\end{array}$ & $\begin{array}{r}0.02 \\
-0.15\end{array}$ & - \\
\hline $\mathrm{N}_{2}$ & $\begin{array}{l}- \text { DNP } \\
+ \text { DNP }\end{array}$ & - & - & $\begin{array}{l}2 \cdot 23 \\
2 \cdot 09\end{array}$ & $\begin{array}{l}4 \cdot 17 \\
4 \cdot 23\end{array}$ & $\begin{array}{r}0.12 \\
-0.09\end{array}$ & $\begin{array}{l}0.262 \\
0.111 \dagger\end{array}$ \\
\hline
\end{tabular}

All values are expressed as $\mu$ mole $/ 10^{8}$ spermatozoa over the experimental period ( $3 \mathrm{hr}$ ) and are the means for four ejaculates incubated in the presence of $25 \mu$ mole fructose and $10 \mu$ mole sorbitol per flask.

Summary of the analyses of variance for fructose utilized, sorbitol and lactate accumulated

\begin{tabular}{|c|c|c|c|c|}
\hline \multirow[b]{2}{*}{ Source of variation } & \multirow[b]{2}{*}{ d.f. } & \multicolumn{3}{|c|}{ Variance ratios } \\
\hline & & $\begin{array}{l}\text { Fructose } \\
\text { utilized }\end{array}$ & $\begin{array}{c}\text { Lactate } \\
\text { accumulated }\end{array}$ & $\begin{array}{c}\text { Sorbitol } \\
\text { accumulated }\end{array}$ \\
\hline $\begin{array}{l}\text { A. Effect of dinitrophenol } \\
\text { B. Effect of gas phase } \\
\text { A } \times \text { B } \\
\text { Ejaculate differences } \\
\text { Ejaculate interactions } \\
\text { (error) }\end{array}$ & $\begin{array}{l}1 \\
1 \\
1 \\
3 \\
9\end{array}$ & $\begin{array}{l}2 \cdot 10 \\
22 \cdot 32 * * \\
5 \cdot 32^{*} \\
9 \cdot 63^{* *} \\
\\
0 \cdot 1026\end{array}$ & $\begin{array}{l}0.58 \\
67 \cdot 09 * * \\
0 \cdot 28 \\
10 \cdot 71^{* *} \\
\\
0.2560\end{array}$ & $\begin{array}{l}4 \cdot 98 \\
1 \cdot 15 \\
0 \cdot 17 \\
1 \cdot 28 \\
0.0332\end{array}$ \\
\hline
\end{tabular}

In the preceding anaerobic experiments (Tables 5,6 and 7) the ratio

$$
\frac{\text { Fructose dismutated ( } \mu \text { mole) }}{\text { Sorbitol accumulated ( } \mu \text { mole })}
$$

was calculated for each flask in which sorbitol was formed during the incubation. In the absence of dinitrophenol sorbitol accumulated in 10 of 11 estimates and the mean ratio was 1.093 with $95 \%$ fiducial limits 0.45 and 1.74 . In the presence of dinitrophenol, however, sorbitol was usually utilized and when the accumulation occurred it was very variable and unrelated to fructose dismutation (see Table 6).

The effect of dinitrophenol on the aerobic and anaerobic metabolism of sorbitol $\left(10 \mu\right.$ mole/flask) by washed ram spermatozoa ( 4 to $7 \times 10^{8}$ cells/ flask) was investigated in the next experiment and the results for the aerobic incubations are shown in Table 8. Sorbitol oxidation was greatly depressed 
by the presence of dinitrophenol but there were no significant effects on its aerobic utilization or on endogenous metabolism. In addition, there was no apparent accumulation of fructose and little lactate accumulation in the experiment. The results of the anaerobic incubations are not included in the Table since any changes in the level of sorbitol that may have occurred were too small to measure. There was, however, a small amount of sorbitol dismutated $\left(0.007 \mu\right.$ mole $/ 10^{8}$ spermatozoa).

In order to measure the aerobic utilization of sorbitol more accurately and to check that there was no anaerobic utilization, a dense suspension (15 to $20 \times 10^{8}$ cells/flask) of washed ram spermatozoa was incubated in the presence of a small amount of sorbitol ( $5 \mu \mathrm{mole} /$ flask $)$. The effect of the addition of potassium chloride $(1 \mathrm{~mm})$ and magnesium chloride $(2 \mathrm{~mm})$ to the diluent was also examined in the experiment. The results for three ejaculates showed

TABLE 8

EFFECT OF $2: 4$ DINITROPHENOL $\left(10^{-4} \mathrm{M}\right)$ ON THE AEROBIC METABOLISM OF WASHED RAM SPERMATOZOA INCUBATED UNDER AEROBIC AND ANAEROBIC CONDITIONS WITH SORBITOL AS SUBSTRATE ( $10 \mu \mathrm{MOLE} /$ FLASK)

\begin{tabular}{c|c|c|c|c}
\hline Treatment & $\begin{array}{c}\text { Total } \mathrm{O}_{2} \\
\text { uptake }\end{array}$ & $\begin{array}{c}\text { Sorbitol } \\
\text { oxidized }\end{array}$ & $\begin{array}{c}\text { Endogenous } \\
O_{2} \text { uptake }\end{array}$ & $\begin{array}{c}\text { Sorbitol } \\
\text { utilized }\end{array}$ \\
\cline { 1 - 2 } - DNP & 1.71 & $\begin{array}{l}0.118 \\
\text { + DNP }\end{array}$ & $\begin{array}{l}0.95 \\
0.37\end{array}$ & $\begin{array}{l}0.16 \\
0.16\end{array}$ \\
\hline
\end{tabular}

All values are expressed as $\mu$ mole $/ 10^{8}$ spermatozoa over the experimental period $(3 \mathrm{hr})$ and are the means for four ejaculates.

** Significant effect of dinitrophenol, $P<0 \cdot 01$.

no effect of the added ions. There was no detectable utilization of sorbitol under anaerobic conditions and in the presence of air, almost all the sorbitol utilized $\left(0.030 \mu\right.$ mole $/ 10^{8}$ spermatozoa) was oxidized to carbon dioxide.

In the preceding experiments, where sorbitol was added as the sole substrate, there were marked differences in the amount of sorbitol oxidized per $10^{8}$ spermatozoa. On inspection, it appeared that this may have been related either to sorbitol concentration or to spermatozoal density. Thus, in Table 5 ( 2 to $5 \times 10^{8}$ cells and $30 \mu$ mole sorbitol/flask), $0 \cdot 204 \mu$ mole sorbitol $/ 10^{8}$ spermatozoa was utilized, in Table 8 ( 4 to $7 \times 10^{8}$ cells and $10 \mu$ mole sorbitol/ flask) $0.118 \mu$ mole was utilized and in the last experiment (15 to $20 \times 10^{8}$ cells and $5 \mu$ mole sorbitol/flask) only $0.030 \mu$ mole was utilized $/ 10^{8}$ spermatozoa. To test these possibilities, washed ram spermatozoa were incubated in the presence and absence of oxygen, at two levels of spermatozoal concentration (3.4 and $13.6 \times 10^{8} /$ flask) and at two sorbitol levels (10 and $5 \mu \mathrm{mole} / \mathrm{flask}$ ). The mean results, together with the summary of the analyses of variance, are given in Table 9. Increase in spermatozoal density increased oxidative metabolism but decreased anaerobic sorbitol dismutation. In the presence of air, an increase in the concentration of sorbitol caused a significant increase in both the utilization and oxidation of this substrate but had no significant 
effect on either total or endogenous respiration. Thus the contribution of sorbitol to total oxygen uptake increased in the presence of the higher concentration of the polyol. With the low spermatozoal concentration and the high sorbitol level, a small amount of lactate $\left(0 \cdot 1\right.$ to $0 \cdot 2 \mu$ mole $/ 10^{8}$ spermatozoa) and fructose $\left(0.04\right.$ to $0.08 \mu$ mole $/ 10^{8}$ cells $)$ accumulated.

In order to measure the accumulation of fructose and lactate more accurately under such conditions, aliquots of three ejaculates of washed ram spermatozoa ( 2 to $3 \times 10^{8}$ spermatozoa/flask) were suspended in $1 \mathrm{ml}$ of basic diluent

TABLE 9

EFFECT OF SUBSTRATE CONCENTRATION AND SPERMATOZOAL DENSITY ON THE METABOLISM OF WASHED RAM SPERMATOZOA WITH SORBITOL AS SOLE SUBSTRATE

\begin{tabular}{|c|c|c|c|c|c|c|c|}
\hline $\begin{array}{c}\text { Gas } \\
\text { phase }\end{array}$ & $\begin{array}{c}\text { Mean sperm- } \\
\text { atozoal density } \\
\left(\times 10^{8} \text { /flask }\right)\end{array}$ & $\begin{array}{c}\text { Sorbitol } \\
\text { conc. } \\
\text { (رmole/flask) }\end{array}$ & $\begin{array}{c}\text { Total } \\
\mathrm{O}_{2} \\
\text { uptake }\end{array}$ & $\begin{array}{c}\text { Sorbitol } \\
\text { oxidized }\end{array}$ & $\begin{array}{l}\text { Endogenous } \\
\mathrm{O}_{2} \text { uptake }\end{array}$ & $\begin{array}{c}\text { Sorbitol } \\
\text { dismutated }\end{array}$ & $\begin{array}{l}\text { Sorbitol } \\
\text { utilized }\end{array}$ \\
\hline Air & $\begin{array}{r}13 \cdot 6 \\
3 \cdot 4\end{array}$ & $\begin{array}{r}10 \\
5 \\
10 \\
5\end{array}$ & $\begin{array}{l}1.44 \\
1.24 \\
0.93 \\
0.91\end{array}$ & $\begin{array}{l}0.129 \\
0.078 \\
0.090 \\
0.065\end{array}$ & $\begin{array}{l}0.60 \\
0 \cdot 77 \\
0 \cdot 34 \\
0.49\end{array}$ & $\begin{array}{l}\bar{z} \\
\overline{-}\end{array}$ & $\begin{array}{l}0 \cdot 15 \\
0 \cdot 06 \\
0 \cdot 30 \\
0 \cdot 11\end{array}$ \\
\hline $\mathrm{N}_{2}$ & $\begin{array}{r}13 \cdot 6 \\
3.4\end{array}$ & $\begin{array}{r}10 \\
5 \\
10 \\
5\end{array}$ & $\begin{array}{c}- \\
-\end{array}$ & $\begin{array}{l}E \\
z\end{array}$ & $\begin{array}{l}- \\
-\end{array}$ & $\begin{array}{l}0.006 \\
0.004 \\
0.024 \\
0.014\end{array}$ & $\begin{array}{r}-0.02 \\
0.00 \\
0.00 \\
-0.05\end{array}$ \\
\hline
\end{tabular}

All values are expressed as $\mu$ mole $/ 10^{8}$ spermatozoa over the experimental period ( $3 \mathrm{hr}$ ) and are the means for four ejaculates.

Summary of the analyses of variance

\begin{tabular}{l|c|c|c|c|c|c}
\hline & & \multicolumn{5}{|c}{ Variance ratios } \\
\cline { 2 - 7 } \multicolumn{1}{c|}{ Source of variation } & d.f. & $\begin{array}{c}\text { Total } \mathrm{O}_{2} \\
\text { uptake }\end{array}$ & $\begin{array}{c}\text { Sorbitol } \\
\text { oxidized }\end{array}$ & $\begin{array}{c}\text { Endogenous } \\
O_{2} \text { uptake }\end{array}$ & $\begin{array}{c}\text { Sorbitol } \\
\text { dismutated }\end{array}$ & $\begin{array}{c}\text { Sorbitol } \\
\text { utilized }\end{array}$ \\
\hline A. Effect of sperm density & 1 & $33 \cdot 24^{* *}$ & $19 \cdot 64^{* *}$ & $11 \cdot 98^{* *}$ & $5 \cdot 92^{*}$ & $3 \cdot 01$ \\
B. Effect of sorbitol conc. & 1 & $2 \cdot 35$ & $43 \cdot 35^{* *}$ & $2 \cdot 72$ & $1 \cdot 15$ & $6 \cdot 26^{*}$ \\
A $\times$ B & 1 & $1 \cdot 41$ & $4 \cdot 63$ & $0 \cdot 01$ & $0 \cdot 46$ & $0 \cdot 70$ \\
Ejaculate differences & 3 & $19 \cdot 73^{* *}$ & $9 \cdot 84^{*}$ & $10.30^{* *}$ & $0 \cdot 19$ & $2 \cdot 10$ \\
Ejaculate interactions (error) & 9 & $0 \cdot 021$ & $0 \cdot 00014$ & $0 \cdot 023$ & $0 \cdot 00013$ & $0 \cdot 012$ \\
\hline
\end{tabular}

$$
\text { * } P<0.05 ; \quad * * P<0.01 \text {. }
$$

containing either 3.2 or $1.6 \mu$ moles of sorbitol of high specific activity ( 313 and $625 \mu \mathrm{mc} / \mu$ mole respectively) and incubated for $3 \mathrm{hr}$ in $5 \mathrm{ml}$ Warburg flasks. After incubation, duplicate aliquots of the protein-free extracts were chromatographed separately on Whatman No. 1 paper strips in a descending system using iso-propanol, acetic acid, water $(3: 1: 1)$ as solvent to separate sorbitol $(\operatorname{Rf} 0.50)$, fructose $(\operatorname{Rf} 0.65)$ and lactate $(\operatorname{Rf} 0.80)$. Chromatograms were scanned in a gas flow counter and the activity of the peaks determined by counting in a liquid scintillation spectrometer and comparing with standards. By this method there was good recovery of the added isotope $(106 \%)$ and as the sorbitol was uniformly labelled, lactate and fructose accumulation could be calculated from the relative activity of the peaks. The results are shown in 
Table 10. As in the previous experiment, an increase in the concentration of sorbitol stimulated its oxidation but had no effect on endogenous respiration. In addition, the small amounts of fructose and lactate which accumulated from sorbitol during the incubation were sensitive to the concentration of the polyol and were almost double in the presence of the higher level.

TABLE 10

METABOLISM OF WASHED RAM SPERMATOZOA IN THE PRESENCE OF LOW CONGENTRATIONS OF SORBITOL OF HIGH SPECIFIG ACTIVITY

\begin{tabular}{|c|c|c|c|c|c|}
\hline $\begin{array}{l}\text { Sorbitol conc. } \\
\text { ( } \mu \text { molelflask) }\end{array}$ & $\begin{array}{c}\mathrm{O}_{2} \\
\text { uptake }\end{array}$ & $\begin{array}{l}\text { Sorbitol } \\
\text { oxidized }\end{array}$ & $\begin{array}{c}\text { Endogenous } \\
\mathrm{O}_{2} \text { uptake }\end{array}$ & $\begin{array}{c}\text { Fructose } \\
\text { accumulated }\end{array}$ & $\begin{array}{c}\text { Lactate } \\
\text { accumulated }\end{array}$ \\
\hline $\begin{array}{l}3 \cdot 20 \\
1 \cdot 60\end{array}$ & $\begin{array}{l}1 \cdot 23 \\
1.05 \dagger\end{array}$ & $\begin{array}{l}0.049 \\
0.030 \div\end{array}$ & $\begin{array}{l}0.91 \\
0.86\end{array}$ & $\begin{array}{l}0.054 \\
0.026\end{array}$ & $\begin{array}{l}0.044 \\
0.016\end{array}$ \\
\hline
\end{tabular}

Values are expressed as $\mu$ mole $/ 10^{8}$ spermatozoa and are the means for three ejaculates.

Summary of the analyses of variance for fructose and lactate accumulated

\begin{tabular}{|c|c|c|c|}
\hline \multirow[b]{2}{*}{ Source of variation } & \multirow[b]{2}{*}{$d . f}$. & \multicolumn{2}{|c|}{ Variance ratios } \\
\hline & & $\begin{array}{c}\text { Fructose } \\
\text { accumulated }\end{array}$ & $\begin{array}{c}\text { Lactate } \\
\text { accumulated }\end{array}$ \\
\hline $\begin{array}{l}\text { A. Effect of substrate concentration } \\
\text { B. Replicate differences } \\
\text { A } \times \text { B } \\
\text { Between duplicates (error) }\end{array}$ & $\begin{array}{l}1 \\
2 \\
2 \\
6\end{array}$ & $\begin{array}{l}9 \cdot 01^{*} \\
4 \cdot 82 \\
1 \cdot 36 \\
0 \cdot 00026\end{array}$ & $\begin{array}{l}31 \cdot 84 * * \\
20 \cdot 11 * * \\
3 \cdot 27 \\
0 \cdot 00007\end{array}$ \\
\hline
\end{tabular}

\section{DISCUSSION}

As well as confirming earlier reports that sorbitol was metabolized aerobically (Mann \& White, 1956, 1957; White, 1957) and that conversion of fructose to sorbitol occurred under both aerobic and anaerobic conditions (King \& Mann, 1959) the results also show that, when both fructose and sorbitol are present, fructose is utilized in preference to sorbitol. At a fructose to sorbitol ratio comparable to that occurring in normal semen (see King \& Mann, 1959) there was practically no change in sorbitol level either due to its utilization or oxidation and a sorbitol to fructose ratio greatly in excess of this was necessary before any substantial utilization of the polyol occurred. It is evident that a dynamic equilibrium between sorbitol and fructose exists since sorbitol oxidation occurred while there was a net formation of sorbitol from fructose.

Under aerobic conditions, the presence of sorbitol had a sparing effect on fructolysis while, at the same time, there was no effect on lactate accumulation. All substrate utilized could be accounted for as $\mathrm{CO}_{2}$ or accumulated lactate and thus it may be inferred that under these conditions, sorbitol is metabolized through the glycolytic cycle. When sorbitol was sole substrate, it was not utilized to the same extent as fructose and possibly the NAD dependent step sorbitol $\rightarrow$ fructose was rate limiting. 
The presence of sorbitol was found to increase the oxygen uptake of washed ram spermatozoa. Nashed, Mixner \& Mather (1964) have reported that increases in fructose concentration stimulate oxygen consumption of bull spermatozoa but, in the present experiment, trebling the concentration of fructose did not affect the metabolism of ram spermatozoa. Thus, in the ram at least, it is presumed that the stimulation of oxygen consumption by sorbitol in the presence of fructose is due to a specific effect of this substance rather than to the presence of additional substrate or non-electrolyte in the incubation medium.

In the experiment to study the effects of time on sorbitol utilization, there was a confounding of time and dilution. The later experiments with sorbitol alone (Table 9) suggest that during the first $1 \frac{1}{2} \mathrm{hr}$ the flasks incubated for $3 \mathrm{hr}$ would utilize sorbitol at a lower rate than the more concentrated suspensions incubated for $1 \frac{1}{2} \mathrm{hr}$. Thus the differences observed are presumably due to changes in the metabolic pattern as the cells age. There is an increase in the use of sorbitol during the longer incubation and this could be due to a rise in the (NAD)/(NADH) ratio with time or to a change in the relative rate of uptake of the two substrates by the cell with time.

Under anaerobic conditions up to $20 \%$ of fructose disappearing accumulated as sorbitol and the remainder was either dismutated or quantitatively converted to lactate. From these experiments, however, it seems unlikely that in ram spermatozoa at least, the accumulation of sorbitol ever accounts for more than $20 \%$ of the fructose utilized under either aerobic or anaerobic conditions. In a study of the anaerobic metabolism of bull spermatozoa, Rothschild (1964) found that approximately $20 \%$ of the fructose disappearing could not be accounted for as lactate formed. This evidence suggests that, in this species, sorbitol may accumulate to an extent similar to that in the ram.

The dismutation of pyruvate has been shown to occur under anaerobic conditions in animal tissues and in bacteria (Krebs \& Johnson, 1937; Krebs, 1937). Pyruvate dismutation occurs in bull and fish spermatozoa (Melrose \& Terner, 1953; Terner, 1959; Terner \& Korsh, 1963) and is partially inhibited by $10^{-4} \mathrm{M} 2: 4$ dinitrophenol. In the present experiments with ram spermatozoa, it is presumed that the ${ }^{14} \mathrm{CO}_{2}$ accumulating under anaerobiosis has its origin in the dismutation reaction. The inclusion of dinitrophenol in the anaerobic flasks caused a similar percentage inhibition of the dismutation reaction as already noted by Terner (1959) and Terner \& Korsh (1963) for other spermatozoa. This inhibition is in marked contrast to the effect of dinitrophenol on aerobic metabolism where a large increase in oxygen uptake and fructose oxidation occurred in its presence. The difference in response under aerobic and anaerobic conditions observed in the present experiments would seem to confirm that the anaerobic reaction is due to pyruvate dismutation and not to residual oxygen.

The decarboxylation of pyruvate occurring as the first stage in the dismutation reaction could increase the availability of reduced nucleotide and help balance the NADH dependent reduction of fructose to sorbitol without interfering with the coupling of the NAD dependent oxidation of triose phosphate to the reductive formation of lactate from pyruvate during normal fructolysis. 
If this were the case it would be expected that 2 moles of sorbitol could be accumulated for every mole of carbon dioxide formed from pyruvate decarboxylation. In the anaerobic experiments reported here, the ratio of fructose dismutated to sorbitol formed was greater than 0.5 in the absence of dinitrophenol. In addition, both fructose dismutation and sorbitol accumulation were decreased by the addition of dinitrophenol although, in its presence, sorbitol accumulation and the dismutation reaction were not interrelated, possibly due to some differential effect of dinitrophenol on the two reactions.

There are some important differences in the effects of dinitrophenol on the oxidative metabolism of sorbitol and fructose. Whereas fructose oxidation is greatly stimulated by its presence and fructose utilization is only slightly affected, both utilization and oxidation of sorbitol are depressed by dinitrophenol. Green, Beyer, Hansen, Smith \& Webster (1963) have pointed out that various dehydrogenases may be influenced by inhibitors and uncouplers of oxidative phosphorylation and that effects secondary to uncoupling may occur when such inhibitors are used. Thus it has been shown that the dismutation of pyruvate, as well as its oxidation, is affected by dinitrophenol (Terner, 1959). Similarly, dinitrophenol may influence dehydrogenase systems responsible for metabolism of sorbitol and so reverse the aerobic effects of dinitrophenol when sorbitol rather than fructose is the substrate.

When sorbitol was the sole substrate, anaerobic utilization could not be measured. Under aerobic conditions a large amount of the sorbitol utilized is oxidized and only small amounts of hexose and lactate accumulate. Also the percentage of oxygen uptake due to exogenous sources is lower when sorbitol, rather than fructose, is the substrate. These observations suggest that the step, sorbitol to fructose, plays a part in limiting the rate of utilization of sorbitol.

As found by Mann \& White (1957), with sorbitol as sole substrate an increase in sorbitol concentration caused an increase in the amount of substrate metabolized. Thus it would seem that sorbitol is made available to the cell by passive diffusion. This is in contrast to fructose where changes in concentration of substrate had no effect on its rate of utilization, suggesting the presence of an active transport mechanism for fructose in ram spermatozoa, as reported in bull spermatozoa (Flipse, 1962). These differences in the mechanisms for uptake of fructose and sorbitol could be a factor in the preferential utilization of fructose when both substances are available to the cell.

\section{ACKNOWLEDGMENTS}

The authors are indebted to Professor C. W. Emmens for interest and criticism. This work was aided by grants from the Rural Credits Development Fund of the Commonwealth Bank of Australia and the Wool Industry Fund. One of us (T.O’S.) was supported by a Walter and Eliza Hall Research Fellowship.

\section{REFERENCES}

Annison, E. F. \& White, R. R. (1961) Glucose utilisation in sheep. Biochem. F. 80, 162.

Barker, J. N. \& Britton, H. G. (1957) The enzymatic estimation of $\mathrm{L}(+)$ lactic acid. 7. Physiol. 138, 3P.

Blackshaw, A. W. (1954) A bipolar rectal electrode for the electrical production of ejaculation in sheep. Aust. vet. 7. 30, 249. 
Blakley, R. L. (1951) The metabolism and antiketogenic effects of sorbitol. Sorbitol dehydrogenase. Biochem. $7.49,257$.

BuHLER, D. R. (1962) A simple scintillation counting technique for assaying $\mathrm{C}^{14} \mathrm{O}_{2}$ in a Warburg flask. Analyt. Biochem. 4, 413.

Flipse, R. J. (1962) Metabolism of bovine spermatozoa. XI. Factors affecting the transport of fructose in bovine spermatozoa. 7 . Dairy Sci. 45, 917.

Green, D. E., Beyer, R. E., Hansen, M., Smtth, A. L. \& Webster, G. (1963) Coupling factors and the mechanism of oxidative phosphorylation. Fed. Proc. 22, 1460.

Hendler, R. W. (1959) Self absorption correction for carbon 14. Science, 130, 772.

Hers, H. G. (1956) Le mécanisme de la transformation de glucose en fructose par les vésicules séminales. Biochim. biophys. Acta, 22, 202.

King, T. E. \& MANN, T. (1958) Sorbitol dehydrogenase in spermatozoa. Nature, Lond. 182, 868.

KING, T. E. \& MANN, T. (1959) Sorbitol metabolism in spermatozoa. Proc. R. Soc. B, 151, 226.

KreBs, H. A. (1937) Dismutation of pyruvic acid in Gonococcus and Staphylococcus. Biochem. J. 31, 661.

Krebs, H. A. \& Johnson, W. A. (1937) Metabolism of ketonic acids in animal tissues. Biochem. 7. 31, 645.

MANN, T. (1948) Fructose content and fructolysis in semen. Practical application in the evaluation of semen quality. 7. agric. Sci. 38, 323.

MANN, T. \& White, I. G. (1956) Metabolism of glycerol, sorbitol and related compounds by spermatozoa. Nature, Lond. 178, 142.

ManN, T. \& White, I. G. (1957) Glycerol metabolism by spermatozoa. Biochem. 7. 65, 634.

Melrose, D. R. \& Terner, C. (1953) The metabolism of pyruvate in bull spermatozoa. Biochem. $\mathcal{F}$. $53,296$.

Nashed, N., Mixner, J. P. \& Matrmer, R. E. (1964) Bovine semen metabolism. VI. Comparative effects of initial fructose level and incubation temperature on fructolysis and sperm motility. 7. Dairy Sci. 47, 87.

RothSchild, LORD (1964) Anaerobic fructolysis, lactic acid and heat production of bull spermatozoa. Proc. R. Soc. B, 159, 291.

Terner, C. (1959) The effects of 2,4-dinitrophenol and p-nitrophenol on the aerobic and anaerobic metabolism of bull spermatozoa. Biochim. biophys. Acta, 36, 479.

Terner, C. \& Korsh, G. (1963) The oxidative metabolism of pyruvate, acetate and glucose in isolated fish spermatozoa. 7. cell. comp. Physiol. 62, 243.

White, I. G. (1957) Metabolism of glycerol and similar compounds by bull spermatozoa. Amer. $\mathcal{F}$. Physiol. 189, 307.

White, I. G. (1959) Studies on the estimation of glycerol, fructose and lactic acid with particular reference to semen. Aust. F. exp. Biol. med. Sci.37, 441.

Wolfson, S. K. \& Williams-Ashman, H. G. (1958) Enzymatic determination of sorbitol in animal tissues. Proc. Soc. exp. Biol. Med. 99, 761. 